\title{
The Influence of Futsal in the Learning Process of Children with Down Syndrome in the Environment School
}

\author{
Igor Felipe Oliveira Bezerra \\ Felipe Rodrigues Gomes \\ Antonio Estanislau Sanches \\ Flanke Duarte Conceição Júnior \\ Nilton Lins University \\ UNINILTON LINS - MANAUS-AM - BRAZIL. \\ Érika Cristina Nogueira Marques Pinheiro \\ Jorge Almeida Brito Júnior \\ Paulista University
UNIP - MANAUS - AM - BRAZIL. \\ Camily Murrieta Vasconcelos Oliveira Bezerra \\ Municipal Secretary of Education \\ SEMED - MAMAUS - AM - BRAZIL.
}

\begin{abstract}
The present research is a bibliographical research, intended to provoke reflections on the influence of futsal on the learning process of children with down syndrome $(S D)$ in the school environment. The child with DS, despite having many of its limited physical and psychological characteristics, has a proven ability to learn. The futsal learning process for children with down syndrome should establish a practice that contextualizes the reality of the student, it is up to the teacher to offer means and strategies to provide the motor, cognitive and affective development of the student with this syndrome, propitiating the construction of knowledge and more complex skills, this will depend on the experiences and experiences provided to the students in the class. In this assumption it is understood that Physical School Education plays a fundamental role of social inclusion, when articulated its pedagogical practice. To reach the established objective, a qualitative research was done, of the bibliographic type. Therefore, it was possible to conclude that the futsal awakens in the students the desire to participate in the class, because it is dynamic, creative and motivating.
\end{abstract}

Keyword: Futsal, Down Syndrome; Physical School Education.

\section{Introduction}

Futsal is a very common practice, providing innumerable benefits to those who practice such as: socialization, physical and mental well-being, work on motor coordination, cognitive work, and other skills. Therefore, the work of futsal with People with Down Syndrome can bring innumerable benefits in the field of motricity, in the cognitive, affective and social field. There is a greater interaction of these people with society in relation to sports practices.

Sports practice may contribute to the development of the person with Down Syndrome. Because it is a change in the genetic formation, Down Syndrome has no cure, but a good education, stimulation and dedication will make the Down Syndrome sufferer develop to its fullest potential.

As a child, the person with the syndrome must be included in Physical Education, it is not enough to be in the same physical space or participate in some activities, but it should be part of the group and participate in all the games and activities developed during the lesson, even who needs help and support from the teacher and other colleagues. However, this support should not become overprotection, because instead of contributing, it tends to hamper the learning process. In this context, the project is based on the authors Duarte and Lima (2003) who talk about futsal adapted to Physical Education for Down Syndrome proponents proposing a direct relation between motor and social activities, offering new experiences in different environments, using games as intermediaries for the understanding of the social and cultural rules, allowing to experience what is or is not accepted in the social life. 
Other authors have been cited to help understand the importance of their contribution to the futsal relationship and its importance in the learning process of children with down syndrome in the school environment. These authors have helped us to understand that, in general, sports practice such as futsal at school contributes to the development of learning of the child with down syndrome.

The main objective of this article is to understand the efficiency of the futsal contribution in the learning process of the child with down syndrome in the school environment. As specific objectives the work will identify the factors that contribute to the development of the child with down syndrome after the insertion of futsal as a sport practice in physical education classes, to investigate the actions of the physical education teacher in the work of futsal sport content in the their classes for the development of the learning of children with down syndrome and to analyze through the literature the extent to which teachers and the school environment provide time and space for futsal as a physical activity for children with down syndrome.

\section{Methodology}

The methodology is a process that has as premise to illustrate not only the products of scientific research, but mainly its own process, because its demands are not strict submission to rigid procedures, but before the fecundity in the production of results (GIL, 2012).

The classification of the data collection technique of this study consists of a bibliographical research, since according to Minayo (2011) it is the foundation that supports the entire research plan, because it is through this theoretical reference that the researcher updates on the indicated subject and increases your theoretical and intellectual knowledge. It is based on material published in books, newspapers, magazines and made available to the general public.

In relation to the classification of the research objectives, this is an exploratory research that, according to Lakatos and Marconi (2013), aims to provide greater familiarity with the problem in order to make it explicit or to facilitate the formulation of the hypothesis. They are used to know the unknown variables, necessary for a more specific and deep investigation.

As for nature, it is classified as a qualitative research, where the researcher seeks to verify a phenomenon by means of its observation and study. According to Minayo (2011) aims to provide a greater knowledge to the researcher on the subject, so that more succinct problems or new hypotheses can be formulated to be researched by future studies.

The procedures were developed based on the bibliographical survey, with the selection of the researched literature, followed by an exploratory analysis, with reading in the whole of the selected material, adopting as organization the relevant categories to answer the research problem, which will be grouped by research interest patterns of interest. The survey was carried out in bibliographic material elaborated in the period between the years of 2009 to 2018 .

\section{School Physical Education Adapted As Sports Practice}

According to the School Physical Education Charter (2007), Physical School Education is a component of the educational system characterized by the emphasis on the concepts, principles, values, attitudes and knowledge of the biodynamic, behavioral and sociocultural dimensions of the human and corporeal movement ; the School Physical Education provides the student, through the conscious practice of corporal activities, the optimization of possibilities and potentialities of development and of harmonious and full body movement.

However, over time, there has been a new evolution in Physical Education, but now in the sense of improving the pedagogical practice that meets the needs of people with disabilities, specified with different definitions for the same term which came to be called Physical Education Adapted (EFA) and / or Special Physical Education (EFE).

For Silva (2004) Adapted Physical Education (EFA) and / or Special Physical Education (EFE) is a modality that aims to provide the total development of the disabled, respecting their individual differences in order to ensure the full right of citizen and effective social integration. This education is provided in the Federal Constitution that ensures this deficient in the regular network of education.

According to Rosa (2014), education is the organization of the individual's biological resources, of all the behavioral capacities that make them adaptable to the physical and mental environment. If individuals are adaptive beings, the forms of integration of any means and situation, certainly can be adapted. Thus, it is argued that physical education is an educational tool of interaction and cooperation, which must be worked out to serve all students; developing physical, recreational and psychomotor activities that develop the skills that socialize individual potentialities.

Unfortunately, the EFA in Brazilian educational policy, from the end of the 1950s to the present day, has been seen as an undesirable part and often attributed as assistance to the disabled, and not as an education for students with disabilities. learning as children with down syndrome (MENDES, 2006). 
The EFA, as a result of these changes, is now a discipline that composes the curricular grade of the initial training courses in EF, aiming to establish lifelong learning relationships for individuals with disabilities through modifications and adaptations in activities geared to the school environment, favoring inclusion (SOUZA, 2014). In this context, the term inclusion is associated with this formation of the future teacher as a result of an educational service whose objective is to encourage all students to reach their school potential, regardless of their abilities or limitations, making the individual with a disability a regular of a regular education system (ALVES; DUARTE, 2014).

In the course of inclusive education, it is no longer acceptable for the student with the disability to integrate himself, but rather for the context to be transformed to allow them to be inserted. Tessaro et al., 2005). In order to achieve this goal, it is necessary to establish a uniform pedagogical framework that addresses the needs of students with disabilities. This is an essential prerogative for inclusion in schools, in this emphasis, the support of physical education seems to be indispensable, since it "occupies a prominent role in the opportunities to know the body culture, to enable the sharing of knowledge and to ensure the effective appropriation of this knowledge by all students "(SALLES; ARAÚJO; FERNANDES, 2015).

But physical education in school should not be thought of as just a sport. It should be thought by influencing the practitioners' daily life through an interdisciplinarity. The educator has to go beyond his area and seek points of contact with other disciplines. It is in interdisciplinarity that the physical education teacher can collaborate for the complete individual and collective development of the students and without excluding the less favored students, whether due to physical, intellectual, social or psychological deficiency (VOLL GROUP, 2017).

We know that not all schools are prepared to receive the student with a disability and for a variety of reasons, among them because teachers do not feel prepared to adequately meet the needs of those students and because non-disabled students have not been prepared on such as accepting or playing with colleagues with disabilities. Perhaps the great difficulty in physical education classes is in attaining at the same time all the students and each one of them. This is because there are no equal people, so diversity becomes a point of analysis in order to avoid failure in education (VOLL GROUP, 2017).

Thus, the future of inclusive education in our country will depend on a collective effort, which will require a review of the position of researchers, politicians, service providers, families and individuals with disabilities, to work towards a common goal that would be to guarantee an education of better quality for all.

\section{Learning In Children With Down Syndrome}

Down Syndrome (DS) was first described in a clinical report of a lecture delivered in 1866 by British physician John Langdon Down, who initially referred to the term mongolism, such a term originated when the physician noted that some children presented appearance common and were not part of the same family and which had similar characteristics to the inhabitants of Mongolia, in east-central Asia, mainly the inclination of the eyes. Such a term is no longer used. Using the proper nomenclature for people with DS is of paramount importance, because the way we refer to and call people can carry prejudices and create negative stigmas from lack of information.

Escribá (2002) reports that individuals with DS often show difficulties in concentration and attention, distracting easily with small stimuli from the environment. It also refers to the lack of initiative to start a task and when they perform it, they show a lot of inconstancy in their accomplishment, showing a tendency to hyperactivity.

The "different" individual has been, over the centuries (and perhaps still is) a target of indifference, detachment, segregation and even repudiation by others. The evolution of the position of the human being before the "different" individuals occurred over the years, passing through four periods: separation; protection; emancipation and; integration. Inclusion can be mentioned as a fifth period, but it is only effective after the consolidation of the integration (MARQUES; CASTRO; SILVA, 2001).

According to Martinho (2016) children with Down syndrome do not develop spontaneous strategies and this is a fact that must be considered in their learning acquisition process, since they will have many difficulties in solving problems and find solutions alone. These difficulties occur mainly because the nervous immaturity and non-myelination of the fibers can hinder mental functions as in the ability to use:

- Abstract concepts;

- Memory;

- General perception;

- Imagination;

- Spatial relationships;

- Body layout;

- Reasoning; 
- Storage of the material learned and;

- Transfer in learning.

This deficiency ends up hampering school activities mainly because it is known that the education of the child is a complex activity, since it requires curricular adaptations that require care and accompaniment of educators and parents SCHWARTZMAN $(1999,233)$.

The teaching of special children should occur in a systematic and organized way, following previously established steps. Teaching should not be theoretical and methodical, it should occur in a pleasant way and that arouses interest in the child. Usually the playful one attracts much the child, in the infancy, and is a resource very used, because it allows the global development of the child through the stimulation of different areas.

There are some pedagogical methods that are applied to Downs, such as:

\section{- Gold Material - Montessori}

The Montessori multisensory method (1948) seeks to combine different sensorial modalities in the teaching of written language to children. By using the auditory, visual, kinaesthetic and tactile modalities, this method facilitates reading and writing by establishing the connection between visual aspects (the orthographic form of the word), auditory (phonological form) and kinesthetic (the movements necessary to write that word).

\section{- Group games}

Through play, children can manifest certain skills that would not be expected for their age. From this manifestation of skills the concept of "proximal zone of development" is created that consists of the distance between what the child can and does do without the help of an adult and what he is able to do with the help of an adult or an older child, who will then perform alone. Therefore, it is in this context that the game can be considered an excellent resource to be used when the child enters the school, since it is an essential part of its nature, being able to favor both the processes that are in formation and others that will be completed (KISHIMOTO , 2007).

For the authors Grigorenko and Tenemberg (2010) learning difficulty is a disturbance in one or more of the basic psychological processes involved in the understanding or use of spoken or written language that can manifest in an imperfect ability to listen, think, speak, read, write, spell or perform mathematical calculations. In order for these learning difficulties to be overcome, satisfactory inclusive education must take place.

\section{Futsal Adapted To the People Learning Process with Down syndrome}

The Futsal that is also called Football Hall is a modality that has been adapted from Football Field for sports courts. With reduced number of players the games are more dynamic and have a fast movement, each team is composed of five players, four players and a goalkeeper, in addition to having seven players.

Due to its practicality, both in the number of players that is very small compared to field soccer, and in the smaller space required, Futsal attracts more and more followers in Brazil and is currently a sport that is always evident in the school educational context. (RINA, SILVA, 2004, p.56).

We know the importance of practicing physical activity and sports in general for people's lives. And in the literature there are several adaptations specifically for each target audience. With Down Syndrome sufferers it is no different as long as these activities.

Physical activity for people with Down Syndrome should be adequate to their characteristics and especially their needs (WINNICK, 2004). According to this same author, the importance of working with psychomotor games is to enable these people to experience the real feelings of practicing something that allows them to work their expectations for the improvement of the motor repertoire and their life experiences as human beings in a teaching process -learning.

People with Down Syndrome suffer from various health problems, and more developmental delays. Problems such as congenital heart disease in $40 \%$ of cases, hypotonia in $100 \%$ of cases, respiratory problems, obesity and premature aging. These problems can be mitigated with the intervention of physical education (ANDRADE, 2005). With this, futsal is a physical activity that can serve to combat the health problems that sufferers suffer from down syndrome. According to Bissoto (2005), futsal will require a wide variety of movements and this will improve or soften problems such as hypotonia, cardiorespiratory condition, balance, obesity and early aging.

Even if the participation of the handicapped in the sport practice is very recent, one can perceive the biopsychosocial beneficios that this practice with pedagogical character offers to these people.It is known that futsal is a collective sport and is practiced in our culture, that is, it will contribute to the integration of society, and it is necessary to consider the limitations of each one's disability (BORGES et al., 2007). 
Physical activity is of paramount importance for the maintenance of quality of life, health and disease prevention. Physical activity for people with down syndrome should be appropriate to their characteristics and especially their needs. Therefore, the importance of working futsal with people with DS, makes them feel real feelings of practicing something that allows them to work their expectations for the improvement of the motor repertoire and their life expectancies as human beings in a teaching- learning (WINNICK, 2004).

It is important to know the main limitations of people with down syndrome, especially those directly involved with them, as this will be able to combat or reduce the prejudice and stigma that these people suffer in society. Even though in a limited way it is important to know that they are capable of performing various activities of either personal or social nature.

Those with Down Syndrome, besides being able to learn the practice of futsal, will also have the opportunity to express themselves through this activity and to try out a sport that is practiced all over Brazil. Therefore, the purpose of futsal for people of the SD is to help them to develop, creating for them an opportunity of leisure, pleasure and mainly of physical and social well-being.

\section{Conclusion}

The Special Physical Education program, such as futsal for people with Down Syndrome, proposes a direct relationship between motor and social activities, offering new experiences in different environments, using games and games as intermediary for understanding social and cultural rules, which is accepted or not in social life.

In this way, it was possible to understand the importance of the sport's contribution to futsal in the school environment in the daily life of the child with down syndrome as a physical activity for the development of learning. As well as identifying the factors that contribute to the development of teaching-learning of the child after the insertion in futsal in the classes of Physical Education. The practice of sport allied to learning, can favor a way for the student to discover new possibilities of intellectual development and knowledge.

Futsal as a sports practice at school aims to promote the development of children's learning, favoring the student's cognitive development and will certainly be helping in a new concept of sport. Thus, it is understood that futsal when based on the development of learning favors the stimulation of a better development of the student. The practices that involve the cognitive study combined with futsal point to new forms of teaching, new discoveries and strategies for the development of learning of the child with Down syndrome.

\section{Referências}

ALVES, Maria Luiza Tanure; DUARTE, Edison. A percepção dos alunos com deficiênciasobre a suainclusãonas aulas de EducaçãoFísica escolar: um estudo de caso. RevistaBrasileira de EducaçãoFísica e Esporte, São Paulo, v. 28, n. 2, p. 329- 338, 2014. Disponívelem: http://www.revistas.usp.br/rbefe/article/view/84074/86907. Acessoem: 10 de abril de 2019.

ANDRADE, S. L. S. Alteraçõesnasociabilidade de criançasportadoras de Síndrome de Down a partir da práticaesportivaemprojeto social napercepção de pais/responsáveis. Rio Janeiro, 2005.

BISSOTO, M.L. O desenvolvimentocognitivo e o processo de aprendizagem do portador de Síndrome de Down: revendoconcepções e perspectivaseducacionais. Ciências\&Cognição. Ano 02, Vol 04, 2005.

BORGES et al. Futebol e basquete: adaptações de regras para o ensino-aprendizagem de alunos com necessidadeseducacionaisespeciais. EFDeportes.com, Revista Digital. Buenos Aires, ano 12- n 112.2007

DUARTE, E. LIMA, S. M. Atividadefísica para pessoas com necessidadesespeciais, intervençõespedagógicas.Editora Guanabara Koogan S.A. 2003.

ESCRIBÁ, A. Síndrome de Down: propuestas de intervención. Madrid: Editorial Gymnos. 2012.

GIL, Antônio Carlos. Métodos e técnicas de pesquisa social. 6ed. São Paulo: Atlas, 2012. LAKATOS, Eva Maria; MARCONI, Marina de Andrade. Fundamentos de metodologiacientífica. 5. ed. - São Paulo: Atlas, 2013.

GRIGORENKO, E. L. STERNBERG, R. J. CriançasRotuladas - O que é Necessário Saber sobre as Dificuldades de Aprendizagem. Porto Alegre: Artmed, 2003.

KISHIMOTO, Tizuko M. (Org.). Jogo, brinquedo, brincadeira e aeducação. São Paulo: Cortez, 1996

MARQUES, R.; CASTRO L. N.; SILVA G. R. A criança e suasdeficiências: métodos e técnicas de açãopsicopedagógica. Rio de Janeiro: Agir, 2001.

MARTINHO, C. I. A. Síndrome De Down - Descobrindo e Trabalhando com aInclusãonaEducaçãoInfantil. 2016.Disponível em: https://www.ebah.com.br/content/ABAAABP6kAE/artigo-cientifico-sindrome-down. Acessadoem 12 de Abril de 2019. 
MENDES, E.G. AEducaçãoInclusiva e a UniversidadeBrasileira. 2006. Disponívelem:

<http://www.ines.org.br/páginas/revista/espaco18/Debate01.pdf>. Acessoem: 10 de abril de 2019.

MINAYO M.C. O desafio do conhecimento: pesquisaqualitativaemsaúde. Rio de janeiro: Abrasco; 2011.

RINA, Mario Sérgio Della; SILVA, Paulo Roberto. "O Jovem e o Esporte".

RevistaPlacar:http://books.google.com.br/books?id=nybgsnrmjdkc\&lpg=pa1\&dq=revistaplacar=732\&hl=pt. br\&pg=pa56\#v=onepag\&q\&f=false. Acessoem: 10 de abril de 2019.

ROSA, Rodrigo Barbosa. EducaçãoFísicaAdaptada e Inclusão no meio Escolar. Portal Educação, 2014. Disponívelem:

https://www.portaleducacao.com.br/conteudo/artigos/educacao-fisica/educacao-fisicaadaptada-e-inclusao-no-meioescolar/56404. Acessoem: 11 de abril de 2019.

SALLES, William das Neves; ARAUJO, Dorival; FERNANDES, Luciano Lazzaris. Inclusão de alunos com deficiêncianaescola: percepção de professores de educaçãofísica.

Conexões, Campinas, v. 13, n. 4, 2015. Disponívelem:

https://periodicos.sbu.unicamp.br/ojs/index.php/conexoes/article/view/8643430/10934. Acessoem: 10 de abril de 2019.

SCHWARTZAN, J. S. Síndrome de Down. São Paulo: Mackenzie, 1999.

SILVA, M. B. da; SCHAPPO, V. L. Introdução a PesquisaemEducação. Florianópolis: UDESC, 2004.

SOUZA, Calixto Souza Junior de. Entre o adaptar e o incluir: umaabordageminterdisciplinar da disciplina de educaçãofísicaadaptada. Revista da Sobama, Marília, v.

15,n.1,p. 31-34, 2014. Disponívelem: http://www2.marilia.unesp.br/revistas/index.php/sobama/article/view/3800/2840. .Acessoem: 10 de abril de 2019.

TESSARO, T.; COMIM, L.; ANCHIETA, C. CORRALO, J.; FUNK, P. P.; GLACOMINI, L. A.; DURANT, V.Criança com Síndrome de Down.Mostra de IniciaçãoCientífica. Universidade de Passo Fundo. 2005.

VOLL GROUP. AImportância da InclusãonaEducaçãoFísica Escolar. Blog sobreEducaçãoFísica para Profissionais e Estudantes - 2017. Disponívelem: https://blogeducacaofisica.com.br/inclusao-na-educacao-fisica/. Acessoem: 11 de abril de 2019.

WINNICK. J.P. EducaçãoFísica e EsportesAdaptados. 3 ed. Barueri. SP: Manole, 2004. 